Research Article

\section{Growth performance of selected Moringa oleifera seed origins in North Florida}

\section{Oluwaseunfunmi Samuel Olaborode*, Cassel Samuel Gardner and Oghenekome Urakpo Onokpise}

College of Agriculture and Food Sciences, Florida Agricultural and Mechanical University,

Tallahassee, FL, USA

\section{Abstract}

Moringa oleifera which is also known as horseradish or drumstick tree is a rapidly growing, drought-tolerant tree that can tolerate poor soil conditions. It is presently broadly cultivated and has turned out to be naturalized in numerous geographical areas of the tropics. The objective of this study was to evaluate the growth performance and survivability of Moringa seed origins in the North Florida region of the United States of America. Seedlings were prepared in the George Conoly Greenhouse at the Florida A\&M University, Tallahassee, FL. The seed origins were Ghana, Texas PKM1, Haiti PKM1, Colombia, Nigeria, Jamaica, Nigeria Local, Impex PKM1, Peela Medu, India EOA PKM1, and Belton. A randomized completely block design (RCBD) was used in this study to compare the performance of eleven seed origins of $M$. oleifera Height and Stem diameter. Nigeria Local had the best performance in terms of height for 2018 and 2019 growing seasons, $191.98 \pm 7.42 \mathrm{~cm}$ and $123.19 \pm 26.67 \mathrm{~cm}$, respectively. Colombia had the best performance in terms of stem diameter for the 2018 and 2019 growing seasons, $2.6 \pm 0 \mathrm{~cm}$ and $2.08 \pm 0 \mathrm{~cm}$, respectively. However, DMRT revealed that the height and stem diameter of the seed origins were not significantly different $(p \leq 0.05)$. Therefore, the results revealed that the alternative hypotheses $\left(\mathrm{H}_{\mathrm{a}}\right)$ that the Moringa oleifera seed origins were significantly different in heights and stem diameter were rejected.
More Information

*Address for Correspondence:

Oluwaseunfunmi Samuel Olaborode, MS College of Agriculture and Food Sciences, Florida Agricultural and Mechanical University, Tallahassee, FL, 32307, USA,

Email: olaborodeseun@gmail.com

Submitted: January 10, 2022

Approved: February 23, 2022

Published: February 25, 2022

How to cite this article: Olaborode OS,

Gardner CS, OnokpiseOU. Growth performance of selected Moringa oleifera seed origins in North Florida. J Plant Sci Phytopathol. 2022; 6: 001-007.

DOI: 10.29328/journal.jpsp.1001066

Copyright: @ 2022 Olaborode OS, et al. This is an open access article distributed under the Creative Commons Attribution License, which permits unrestricted use, distribution, and reproduction in any medium, provided the original work is properly cited.

Check for updates

OPEN ACCESS

\section{Introduction}

Moringa oleifera is a rapidly growing, drought-tolerant tree that can tolerate poor soil conditions [1]. Also known as the horseradish tree, drumstick tree, Benzolive tree, Kelor, Marango, Mlonge, Moonga, Mulangay, Nébéday, Saijhan, Sajna or Ben oil tree, it was used by the old Romans, Greeks, and Egyptians [2]. The maximum temperature for growth and development of the tree ranges from 38 to $48{ }^{\circ} \mathrm{C}$ and at least -1 to $3{ }^{\circ} \mathrm{C}$. A soil quite sandy in texture favors the cultivation of M. oleifera, though it grows in most other than stiffy clay of shallow hills [3]. The M. oleifera ranges between $5 \mathrm{~m}$ to $12 \mathrm{~m}$ in height. M. oleifera is evergreen in tropical regions, while deciduous in sub-tropical climates. The canopy has an umbrella-like crown with bi-(tri-) pinnate leaves, while the individual leaflet area of one to two $\mathrm{cm}^{2}$ [2]. The tree grows well in a climate ranging from warm tropical at sea level to subtropical up to an altitude of 3,000 ft [4]. Moringa oleifera is the most broadly cultivated plant among the monogeneric family, the Moringaceae, that is native to the sub-Himalayan tracts of
India, Pakistan, Bangladesh, and Afghanistan. It is presently broadly cultivated and has turned out to be naturalized in numerous areas of the tropics. It's an angiosperm having timber of low quality but its growing importance as a medicinal plant in India, Ethiopia, the Philippines, and Sudan has led to its development in the West, East, Southern Africa, and tropical Asia for its medicinal uses [2]. Each part of the Moringa tree (leaves, flowers, fruits, seeds, bark, and roots) is associated with the presence of at least one, or in the greatest number of benefits [5]. Dietary iron supplements analysis in the liver influenced the consumption of M. oleifera leaves revealed that iron from Moringa can inhibit iron deficiency [6].

Although moringa has many species, Moringa oleifera is the most adapted plant worldwide compared to other species of moringa. M. oleifera is the most widely recognized moringa species throughout the world [7]. M. oleifera is cultivated throughout Senegal and it is commonly used as a living fence around compounds in villages. M. oleifera growing in African countries revealed that the seeds germinate within 5 to 12 
days and are transplanted at the height of 60 to 90 centimeters (cm). M. oleifera can tolerate up to 6 months of dry season reasonably well; however, prolonged stress from lack of water can lead to loss of leaves [3].

Optimum temperature differs between plant species, growth conditions and is higher in elevated atmospheric $\mathrm{CO}_{2}$. With increasing temperature, vapor pressure deficits of the air may increase, with a concomitant increase in the transpiration rate from plant canopies [8], which has a direct impact on photosynthesis just as the development and growth of plants. The temperature has an impact on the natural geographical plant distribution, tree performance, physiology, and productivity [9]. Moringa oleifera production ought to be expanded in climatically fit locations because of the numerous benefits it offers to mankind. As Moringa oleifera trees favor hot and humid environments, its trees are for the most part found in tropical regions around the world. There is a need to expand the production areas of Moringa oleifera past the tropics and to determine the impact that cooler growing temperatures have on the moringa plant.

Considering the versatility of $M$. oleifera, its commercialization would be of great benefit as it will lead to increased production areas into cooler climates. The performance of moringa trees at low growing temperatures is thus far unknown, and this prompted the investigation into plant growth in the North Florida region. Overall plant growth is governed by two separate growth processes namely primary and secondary growth. Primary growth is responsible for the increase in plant height, while stem thickening is the result of secondary thickening growth [10]. Plant height and stem diameter were therefore the measured parameters to test for the effects of the North Florida climate on the plant growth of M. oleifera.

\section{Materials and methods}

\section{Study site}

This research was conducted at George Conoly Greenhouse on the main FAMU Campus and the Florida A\&M University Research and Extension Center Quincy, FL, USA $\left(30^{\circ} 32^{\prime} 42.288^{\prime \prime} \mathrm{N} 84^{\circ} 35^{\prime} 45.06^{\prime \prime} \mathrm{W}\right)$.

\section{Seedling preparation}

Seedlings were prepared in the George Conoly Greenhouse at the Florida A\&M University, Tallahassee, FL. Eleven (11) Moringa seed origins were donated by Mr. Rodney Perdew of Moringa Farms Inc (Tallahassee, FL). The seed origins were Ghana, Texas PKM1, Haiti PKM1, Colombia, Nigeria, Jamaica, Nigeria Local, Impex PKM1, Peela Medu, India EOA PKM1, and Belton. Seeds were sown into peat cups. One seed was sowed per cup, the soil was made from Fafard 3 Mix (SunGro) that consists of Canadian sphagnum peat moss, bark, vermiculite, perlite, dolomitic limestone, wetting agent, and sand. The temperature at which they were grown in the greenhouse was $21-24{ }^{\circ} \mathrm{C}$ (Figure 2). Seedlings were not grown with the use of fertilizers or pesticides, they were then transferred to a prepared plot at the Florida A\&M University Research and Extension Center, Quincy, FL. U.S.A.

\section{Soil sampling of the field number 19 of FAMU-REC}

Soil sampling was done using a soil probe to take soil samples at a depth of $30 \mathrm{~cm}$. Samples were taken systematically in a zig-zag manner and were properly mixed to ensure homogeneity of the soil sample. Soil samples were sent to Waters Agricultural Laboratory, Camilla, GA, the USA for analysis. The soil $\mathrm{pH}$ and Buffer $\mathrm{pH}$, Phosphorus (P), Potassium $(\mathrm{K})$, Magnesium (Mg), Calcium (Ca), Sulfur (S), Boron (B), Zinc (Zn), Manganese (Mn), Iron (Fe) and Copper (Cu) in kg/ ha (kilograms/hectare) are shown in Table 1 . Initial results were obtained in pounds/acre (lbs/a) but were converted to kilogram/hectare $(\mathrm{kg} / \mathrm{ha})$. Base saturation in percentage was calculated using the following formula:

- $\quad \mathrm{H}, \mathrm{meq} / 100 \mathrm{~g}$ soil $=8$ (8.00 - buffer $\mathrm{pH})$

- $\mathrm{K}, \mathrm{meq} / 100 \mathrm{~g}$ soil $=\mathrm{lbs} /$ acre extracted $\mathrm{K} \div 782$

- $\mathrm{Mg}$, meq/100 g soil = lbs/acre extracted $\mathrm{Mg} \div 240$

- $\mathrm{Ca}$, meq/100 g soil $=\mathrm{lbs} /$ acre extracted $\mathrm{Ca} \div 400$

- $\mathrm{Na}$, meq/100 g soil $=\mathrm{lbs} /$ acre extracted $\mathrm{Na} \div 460$

Soil composition: Minerals such as phosphorus, sulfur, boron, zinc, manganese, and copper were low while the iron was the only adequate mineral. potassium, magnesium, and calcium were classified as medium.

\section{Experimental design and spatial arrangement}

A randomized completely block design (RCBD) was used for this study for all eleven moringa seed origins. The field plot measured $75.59 \mathrm{~m}$ in length and $22.86 \mathrm{~m}$ in width. There were three replications. Each of the 11 seed origins had six moringa seedlings in each of the replicates. A total of 198 seedlings were used for this study (66 seedlings in each of the three replicates). In each replicate, there was a $2 \mathrm{~m}$ spacing within

Table 1: Soil nutrients, the concentration of nutrients expressed in $\mathrm{kg} / \mathrm{ha}$. Section 19 of FAMU-REC.

\begin{tabular}{|c|c|c|c|}
\hline Type of Analysis & Unit & Value & Soil Ratings \\
\hline Phosphorus $(\mathrm{P})$ & $(\mathrm{kg} / \mathrm{ha})$ & 6.74 & Low \\
\hline Potassium $(\mathrm{K})$ & $(\mathrm{kg} / \mathrm{ha})$ & 83.15 & Medium \\
\hline Magnesium $(\mathrm{Mg})$ & $(\mathrm{kg} / \mathrm{ha})$ & 116.85 & Medium \\
\hline Calcium $(\mathrm{Ca})$ & $(\mathrm{kg} / \mathrm{ha})$ & 542.69 & Medium \\
\hline Sulfur $(\mathrm{S})$ & $(\mathrm{kg} / \mathrm{ha})$ & 11.24 & Low \\
\hline Boron $(\mathrm{B})$ & $(\mathrm{kg} / \mathrm{ha})$ & 0.45 & Low \\
\hline Zinc $(\mathrm{Zn})$ & $(\mathrm{kg} / \mathrm{ha})$ & 2.02 & Low \\
\hline Manganese $(\mathrm{Mn})$ & $(\mathrm{kg} / \mathrm{ha})$ & 17.98 & Low \\
\hline Iron $(\mathrm{Fe})$ & $(\mathrm{kg} / \mathrm{ha})$ & 23.6 & Adequate \\
\hline Copper $(\mathrm{Cu})$ & $(\mathrm{kg} / \mathrm{ha})$ & 0.34 & Low \\
\hline Soil $\mathrm{pH}$ & - & 6 & - \\
\hline Buffer $\mathrm{pH}$ & - & 7.7 & - \\
\hline
\end{tabular}


each moringa seed origin. The space between one replicate and the other was $9.03 \mathrm{~m}$. Seeds were sown in April 2018 in the Greenhouse and were transplanted July 2018 (Figures $1,2)$.

\section{Field data collection procedures}

Height measurement: Plant heights were measured for the data collection on the $19^{\text {th }}$ of November 2018. Heights were measured from the ground to the terminal bud of the plant, the height of all plants was measured by a meter stick (Conway-Cleveland Corp). This was done after 4 months of transplanting in 2018. Plants became dormant at the end of 2018 due to frost. Visible growth was noticed in April 2019. Monthly height measurement was done till November 2019 when the biomass was determined.

Stem diameter determination: Stem diameter was taken by an electronic digital caliper (Carbon Fiber Composites). The measurement was taken $3 \mathrm{~cm}$ from the ground to ensure
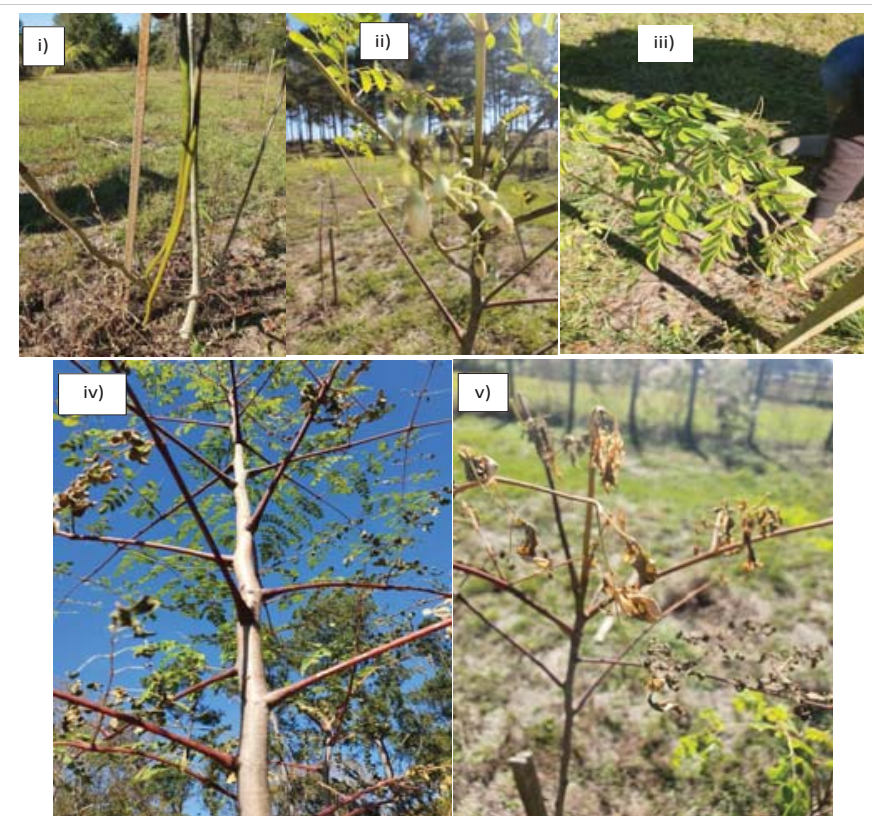

Figure 1: Different vegetative and reproductive parts of Moringa oleifera plants grown at the FAMU Research and Education Center (FAMU-REC), Quincy, Florida. i) pods; ii) flowers; iii) foilage; iv) matured moringa tree; v) moringa foilage under a low temperature of $2.8^{\circ} \mathrm{C}$. Leaves are drought tolerant but are not cold tolerant.

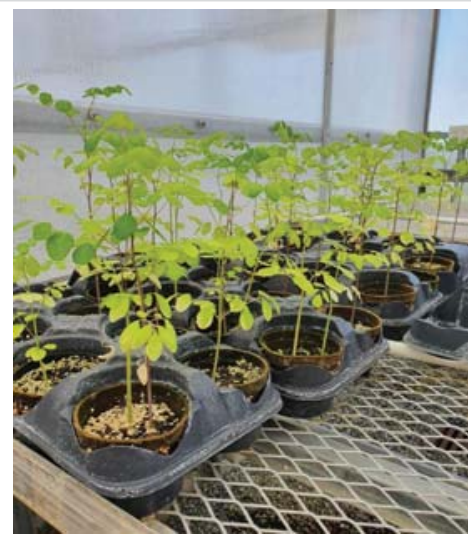

Figure 2: Moringa seedlings in the George Conoly Greenhouse FAMU Campus. uniformity in the data collection procedure. This was done after 4 months of November 2018, and monthly from July until November 2019, when the plant biomass was determined.

Growth rate: Growth rate was determined by subtracting the initial height and stem diameter of the next month from the previous month, dividing by the next month, and multiplying by $100 \%$. The growth rate was expressed in percentage by the following: Final growth- initial growth /Final growth $\times 100 \%$.

Biomass determination: Plant biomass was determined by cutting down all moringa plants in each replicate at $3 \mathrm{~cm}$ from the ground, each of them was properly labeled for easy identification, they were weighed, and weight was recorded.

Vegetative propagation: Vegetative propagation was attempted to see if the moringa seeds could be propagated by stem cuttings. After taking the weight of the harvested moringa plants at the Florida A\&M University Research and Extension Center at Quincy, Florida. The plants were taken to the George Conoly Greenhouse. The propagation had to be done the same day to decrease the risk of non-viability of the stem cuttings. 18 stem cuttings from each seed origin were used for this study. 9 stem cuttings from each of the seed origins were propagated with the use of rooting hormone (Bontone ${ }^{\circledR I}$ Rooting powder) purchased at Esposito Garden Center, Tallahassee, FL while the other set of 9 cuttings from each of the seed origins was propagated without rooting hormone. This was done to check the response of the seed origins when they are propagated without rooting hormone and with rooting hormone.

Statistical analysis: The data generated were subjected to analysis of variance using the IBM SPSS statistical package [11] (Version 26.0) 2019 edition. Significant treatment means were tested at a $5 \%$ level of probability using the Duncan Multiple Range Test (DMRT). Charts were created using MATLAB and Microsoft Excel 2016. Correlation coefficients were not determined and not reported.

\section{Results on moringa growth performance}

Plant height and stem diameter: Of the 11 moringa seed

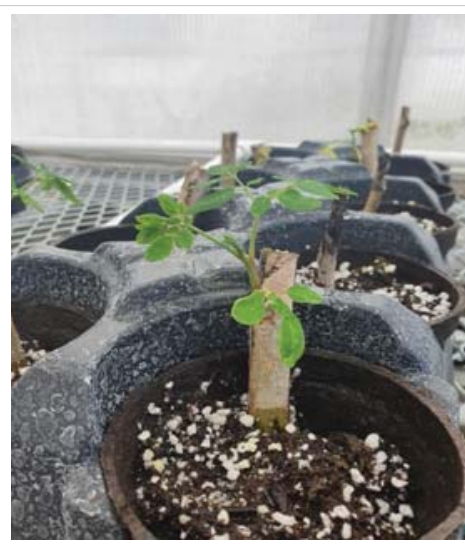

Figure 3: Visible leaf sprouts in vegetative propagation of moringa cuttings at the George Conoly Greenhouse. 
origins used, all were able to grow except the seed from Belton which did not survive in the field. Belton seed origin was able to germinate in the Greenhouse at a regulated temperature of $21{ }^{\circ} \mathrm{C}-24{ }^{\circ} \mathrm{C}$ like the rest of the seeds. But its non-survivability in the field might be because of soil nutrients and/or North Florida weather conditions.

There were differences in the average height of plants in 2018 and 2019. Plants had a higher height in 2018 because of the amount of annual rainfall. There was an annual rainfall of $2029.46 \mathrm{~mm}$ in 2018 while there was an annual rainfall of $993.14 \mathrm{~mm}$ [12], this is a $51.06 \%$ decrease in the amount of annual rainfall for the 2019 growing season. Nigeria's Local seed origin had the highest height for both seasons with a mean height of $191.98 \mathrm{~cm}$ in November 2018 and $123.19 \mathrm{~cm}$ in November 2019 while Nigeria had the least growth with a mean height of $53.16 \mathrm{~cm}$ in November 2018 and $95.25 \mathrm{~cm}$ in November 2019. Seed origins from Colombia and Impex PKM1 had plant heights close to each other for both seasons (Table 2). Colombia seed origin had the highest mean stem diameter for both seasons with a mean stem diameter of $2.6 \mathrm{~cm}$ in November 2018 and $2.08 \mathrm{~cm}$ in November 2019. Nigeria had the least mean stem diameter for both seasons with a mean stem diameter of $0.84 \mathrm{~cm}$ in November 2018 and $0.76 \mathrm{~cm}$ in November 2019 (Table 3). Figure 5 presents the percentage growth rate of moringa seed origins from July 2019 to November 2019, the plant heights in the October and

Table 2: Mean height of moringa seed origins of M.oleifera in November 2018 and November 2019.

\begin{tabular}{|c|c|c|}
\hline Seed origin & Height in November 2018 (cm) & Height in November 2019 (cm) \\
\hline Ghana & $152.4 \pm 0^{\mathrm{a}}$ & $64.135 \pm 0^{\mathrm{b}}$ \\
\hline Texas PKM1 & $91.02 \pm 9.27^{\mathrm{a}}$ & $97.52 \pm 54.05^{\mathrm{b}}$ \\
\hline Haiti PKM1 & $108.66 \pm 15.47^{\mathrm{a}}$ & $98.81 \pm 39.57^{\mathrm{b}}$ \\
\hline Colombia & $173.14 \pm 21^{\mathrm{a}}$ & $106.26 \pm 0^{\mathrm{b}}$ \\
\hline Nigeria & $95.25 \pm 5.38^{\mathrm{a}}$ & $53.16 \pm 16.27^{\mathrm{b}}$ \\
\hline Jamaica & $121.21 \pm 18.36^{\mathrm{a}}$ & $76.91 \pm 26.47^{\mathrm{b}}$ \\
\hline Nigeria Local & $191.98 \pm 7.42^{\mathrm{a}}$ & $123.19 \pm 26.67^{\mathrm{b}}$ \\
\hline Impex PKM1 & $161.93 \pm 13.08^{\mathrm{a}}$ & $108.96 \pm 52.02^{\mathrm{b}}$ \\
\hline Peela Medu & $101.6 \pm 0^{\mathrm{a}}$ & $55.88 \pm 0^{\mathrm{b}}$ \\
\hline India EOA PKM1 & $113.35 \pm 1.38^{\mathrm{a}}$ & $58.42 \pm 12.7^{\mathrm{b}}$ \\
\hline
\end{tabular}

Mean \pm SD values with the same superscript along the same column are not significantly different according to Duncan Multiple Range Test (DMRT) $(p \leq 0.05)$.

Table 3: Mean stem diameter of seed origins M.oleifera at November 2018 and November 2019

\begin{tabular}{|c|c|c|}
\hline Seed origin & $\begin{array}{c}\text { Stem Diameter in } \\
\text { November 2018 }(\mathbf{c m})\end{array}$ & $\begin{array}{c}\text { Stem Diameter in } \\
\text { November 2019 (cm) }\end{array}$ \\
\hline Ghana & $1.143 \pm 0^{\mathrm{a}}$ & $0.91 \pm 0^{\mathrm{b}}$ \\
\hline Texas PKM1 & $1.59 \pm 0.98^{\mathrm{a}}$ & $1.3 \pm 0.69^{\mathrm{b}}$ \\
\hline Haiti PKM1 & $2.79 \pm 0.76^{\mathrm{a}}$ & $1.97 \pm 1.27^{\mathrm{b}}$ \\
\hline Colombia & $2.6 \pm 0^{\mathrm{a}}$ & $2.08 \pm 0^{\mathrm{b}}$ \\
\hline Nigeria & $0.84 \pm 0.21^{\mathrm{a}}$ & $0.76 \pm 0.11^{\mathrm{b}}$ \\
\hline Jamaica & $1.70 \pm 0.11^{\mathrm{a}}$ & $1.28 \pm 0.17^{\mathrm{b}}$ \\
\hline Nigeria Local & $1.67 \pm 0.43^{\mathrm{a}}$ & $1.23 \pm 0.24^{\mathrm{b}}$ \\
\hline Impex PKM1 & $1.86 \pm 0.77^{\mathrm{a}}$ & $1.44 \pm 0.67^{\mathrm{b}}$ \\
\hline Peela Medu & $1.11 \pm 0^{\mathrm{a}}$ & $0.89 \pm 0^{\mathrm{b}}$ \\
\hline India EOA PKM1 & $1.15 \pm 0.04^{\mathrm{a}}$ & $0.86 \pm 0.03^{\mathrm{b}}$ \\
\hline
\end{tabular}

Mean $\pm S D$ values with the same superscript along the same column are not significantly different according to Duncan Multiple Range Test $(p \leq 0.05)$.
November for all seed origins were very close, this shows how cold temperature impacts the height of moringa seed origins. Table 4 presents the regression equations for plant height and stem diameter over 150 days growing period in 2019. The regression equation helps to estimate the plant height and stem diameter of moringa seed origins at a specific time.

Growth rate: The result on the growth rate which is expressed in percentages shows that for the Plant heights, the highest growth rate was noticed in the month of August, and there was a steady reduction in the percentage growth rate as colder months were approached (Figure 5). Stem diameter growth was not badly impacted by cold as there was a higher percentage growth rate as colder months were approached compared to the plants' heights.

Biomass determination: The Biomass result shows that Peela Medu and Nigeria's Local seed origins had the least biomass, weighing $22.65 \mathrm{~g}$ and $23.63 \mathrm{~g}$ respectively while Haiti PKM1 weighed 254.72 g (Figure 6).

Vegetative propagation: Ghana, Nigeria, and Colombia seed origins had $0 \%$ leaf sprout with rooting hormone, Jamaica seed origin had a good response to vegetative propagation with both rooting hormone and non-rooting hormone with $55.46 \%$ and $88.89 \%$ leaf sprout, respectively. Jamaica seed origin is the best seed origin for vegetative propagation, this means seeds will not be necessarily needed when growing Jamaica moringa seed origin in North Florida and similar climatic conditions.

\section{Discussion}

The highest growth in heights for all Moringa oleifera seed origins was observed in Nigeria Local for both seasons (November 2018 and November 2019) with the heights $191.98 \mathrm{~cm}$ and $123.19 \mathrm{~cm}$, respectively (Figure 3). The highest growth in stem diameter for all Moringa oleifera seed origins was observed in Colombia for both seasons (November 2018 and November 2019) with stem diameters $2.60 \mathrm{~cm}$ and 2.08 $\mathrm{cm}$ (Figure 4). The result could be attributed to the more

Table 4: Regression equation parameters of plant height and stem diameter as a function of days after noticeable germination in the 2019 growing season over a period of 150 days (July to November).

\begin{tabular}{|c|c|c|c|c|c|c|}
\hline & \multicolumn{3}{c}{ Height (cm) } & \multicolumn{3}{c|}{ Stem Diameter (cm) } \\
\hline Seed Origin & Slope & Intercept & $\mathbf{R}^{2}$ & Slope & Intercept & $\mathbf{R}^{2}$ \\
\hline Ghana & 0.1510 & 43.715 & 0.9115 & 0.0024 & 0.5461 & 0.9538 \\
\hline Texas PKM1 & 0.3708 & 47.507 & 0.9076 & 0.0034 & 0.8092 & 0.933 \\
\hline Haiti PKM1 & 0.4091 & 44.718 & 0.8821 & 0.0066 & 0.9256 & 0.9657 \\
\hline Colombia & 0.3313 & 63.847 & 0.7303 & 0.0084 & 0.8814 & 0.96306 \\
\hline Nigeria & 0.1882 & 27.057 & 0.9573 & 0.0013 & 0.5742 & 0.9974 \\
\hline Jamaica & 0.1453 & 57.460 & 0.7765 & 0.0026 & 0.9011 & 0.9894 \\
\hline Nigeria Local & 0.5118 & 53.594 & 0.9212 & 0.0020 & 0.9507 & 0.9435 \\
\hline Impex PKM1 & 0.4694 & 48.376 & 0.7852 & 0.0050 & 0.7633 & 0.8599 \\
\hline Peela Medu & 0.2498 & 23.622 & 0.7826 & 0.0027 & 0.4978 & 0.9771 \\
\hline India EOA & 0.1975 & 30.411 & 0.9632 & 0.0012 & 0.6788 & 0.9691 \\
\hline PKM1 & & & & & & \\
\hline
\end{tabular}

$\mathrm{Y}=\mathrm{at}+\mathrm{b}$. where $\mathrm{Y}=$ Dependent variable (Height $/$ Stem diameter $) \mathrm{a}=$ slope, $\mathrm{b}=$ intercept and $t=$ days after noticeable germination. 

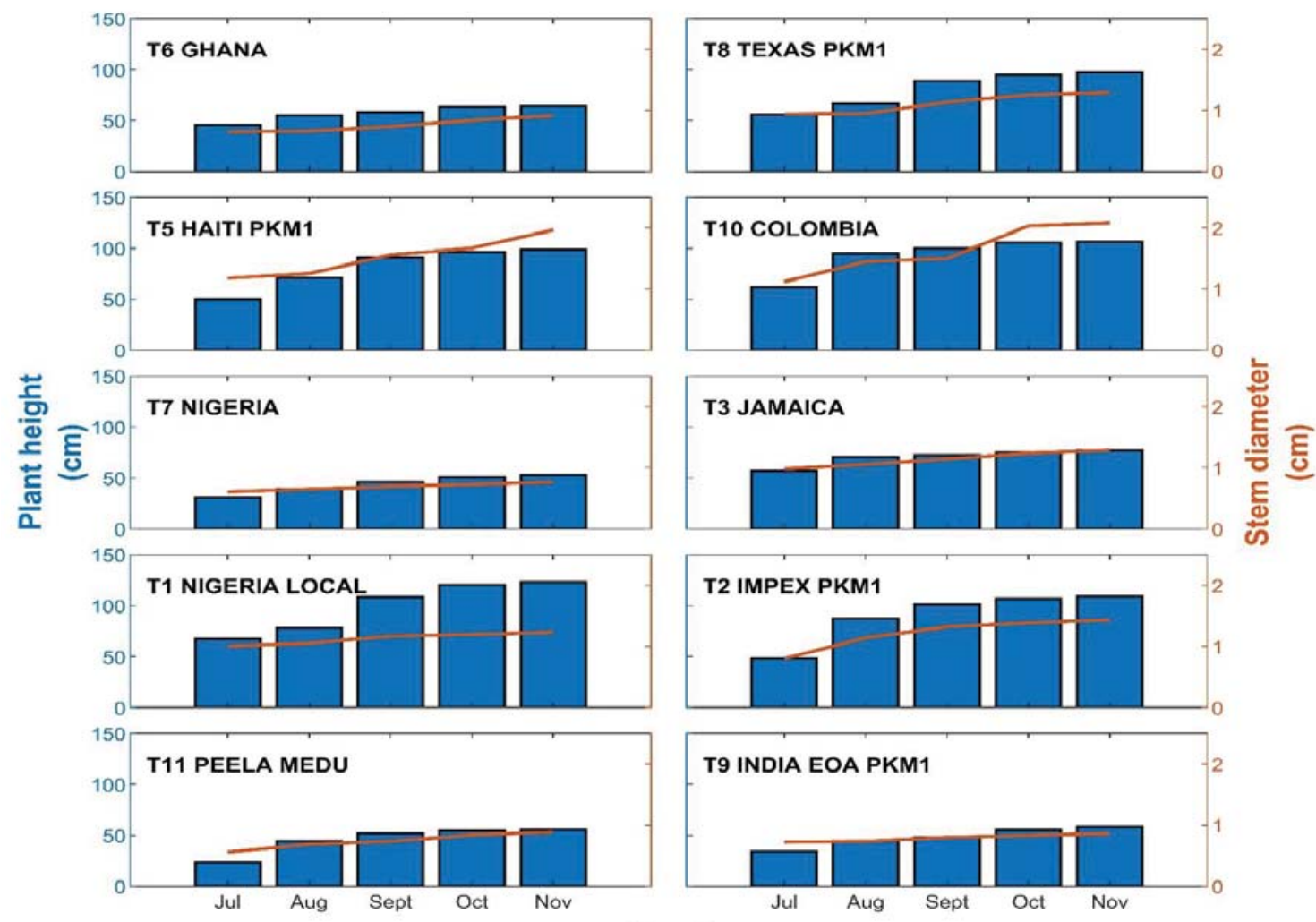

Month

Figure 4: Different vegetative and reproductive parts of Moringa oleifera plants grown at the FAMU Research and Education Center (FAMU-REC), Quincy, Florida. i) pods; ii) flowers; iii) foilage; iv) matured moringa tree; v) moringa foilage under a low temperature of $2.8^{\circ} \mathrm{C}$. Leaves are drought tolerant but are not cold tolerant.

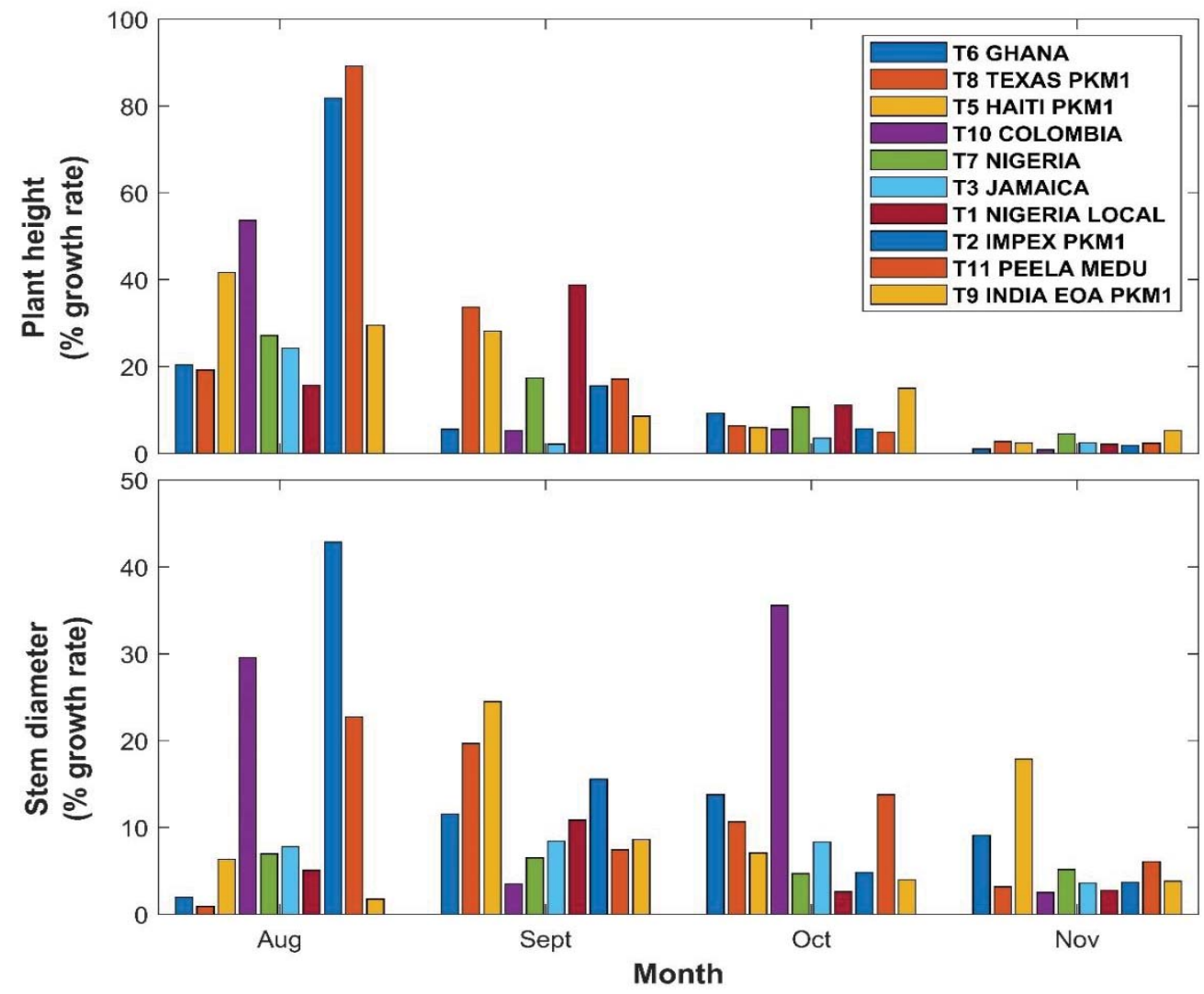




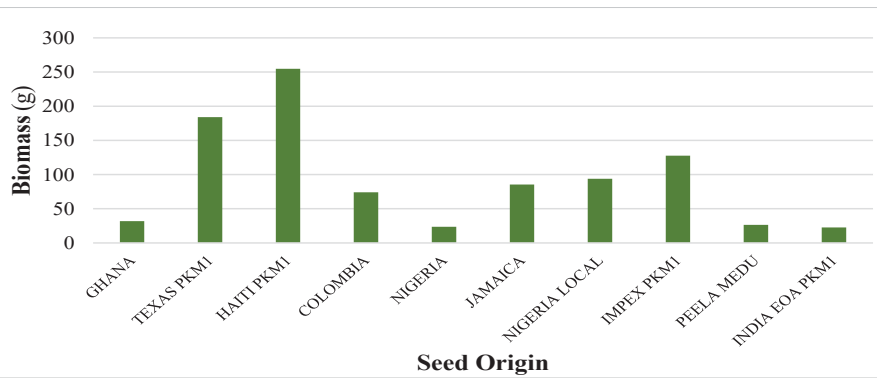

Figure 6: Mean biomass of seed origins. Biomass of seed origins not significantly different at $p \leq 0.05$ according to Duncan Multiple Range Test.

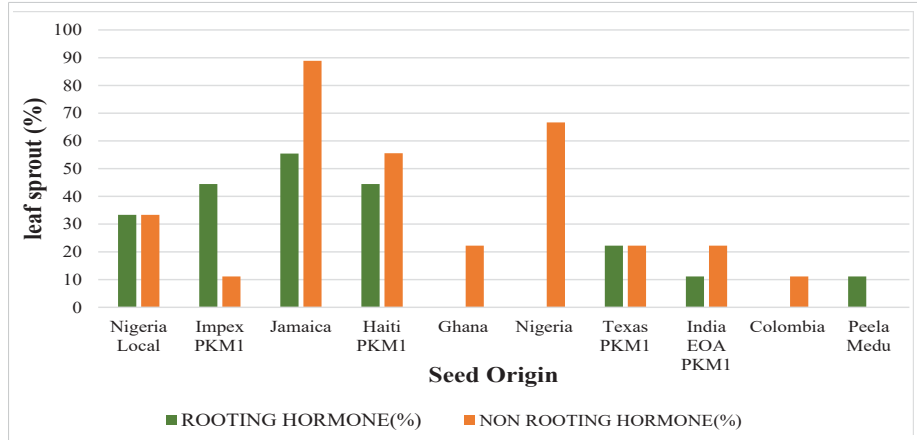

Figure 7: Vegetative propagation response of stem cuttings to rooting hormone and non-rooting hormone for moringa seed origins.

rainfall in the year 2018 than the year 2019 with the annual rainfall measuring $2029.46 \mathrm{~mm}$ and $993.14 \mathrm{~mm}$ respectively in North Florida. With a $51.06 \%$ decrease in rainfall in the second growing season (2019), Nigeria's Local seed origin grew faster and had the highest height compared to the other seed origins (Figure 5). Moringa oleifera is an extremely fastgrowing tree species that takes 4-5 months to mature, is well adapted to droughts, and can reach a height of $400 \mathrm{~cm}$ in a year, and eventually, 600 to $1500 \mathrm{~cm} \mathrm{[1,9].}$

With North Florida having a sub-tropical climate, plants grow more rapidly during the summer season (May to August) and wet season (September to November) after which winter (December to February) sets in and affects the plant growth negatively. This explains the maximum growth rate of plant heights observed in August and September and the minimum growth rate of plant heights in November for all the moringa seed origins (Figure 5). Belton seed origin did not survive on the field for both the 2018 and 2019 seasons. The lowest height observed in 2018 was Texas PKM1 with a mean height of $91.02 \mathrm{~cm}$ while the lowest height observed in 2019 was Nigeria seed origin with a mean height of $53.16 \mathrm{~cm}$, Nigeria seed origin had a mean height of $95.25 \mathrm{~cm}$ in 2018. Korsor, et al. [12] reported that young moringa trees have a long delay in sprouting after the winter dormancy compared to older trees, which is attributed to shallow and deep roots establishment, respectively. Billings, [13] discussed that all environments and all environmental stressors are not equal in relation to their effects on plant growth, development, and reproduction; nor do all kinds of plants equally adapt to environmental changes or have the same level of coping with stress factors. Favorably, Moringa plants are droughtresistant and do better despite the scarcity of water when fully established as described by Alhakmani, [1].

Within seed origins, heights were higher in each seed origin in the first growing season than in the second growing season except for the Texas PKM1 seed origin which the first growing season had a lower height than the second growing season with heights of $91.02 \mathrm{~cm}$ and $97.52 \mathrm{~cm}$, respectively. The analysis revealed that seed origins of Moringa oleifera are not significantly different $(p \leq 0.05)$ in mean heights and stem diameter. This implies that all moringa seed origins did not have different heights and stem diameters in the two seasons and that the seeds can be grown in North Florida and similar climatic conditions. The lower height of the Nigeria seed origin in the second growing season might be attributed to the first focus on underground growth of the roots into tubers to preserve energy for rough conditions (winter/drought) as described by Korsor, et al. [14]. The moringa seed origins are suitable to the North Florida region in this order: Nigeria local, Colombia, Impex PKM1, Ghana, Jamaica, India, Haiti, Peela Medu, Nigeria, and Texas PKM1.

In the first growing season, plant height and stem diameter were the only traits measured among the moringa seed origins in November 2018. The above-ground parts of the plants were affected by frost in December 2018. Noticeable resprout of these plants was observed in June 2019. Therefore, monthly plant height and stem diameter data were taken in the subsequent months (July -November of 2019). The plants were harvested and weighed for the total above-ground biomass. Cuttings of stem for vegetative propagation were carried out. Moringa oleifera has high resistance to drought and arid conditions owing to their tuberous roots. It develops tubers that store energy for use during adverse conditions (survival mechanism). This could be the reason why in most cases the stems of Moringa oleifera die during harsh conditions and sprout soon after conditions improve $[14,15]$.

Percentage monthly growth rate (Figure 5) of plant heights was observed to be highest in the month of August and was also observed to be the lowest in the month of November, this shows that as the colder months approached there was a reduction in the percentage monthly growth rate for plant heights. Plant growth is most active during the first months of planting under favorable environmental conditions as reported by Li \& Siddique, [4]. However, it is different for the percentage monthly growth rate for stem diameter as the stem diameter growth was not badly impacted by cold. There was a higher percentage growth rate in the stem diameter as colder months were approached compared to the percentage growth rate of plant height. Moringa oleifera trees could be tolerant to light frosts but cannot survive as a perennial crop under freezing conditions [16]. Moringa has a high growth rate and capacity to produce large quantities of fresh biomass [17]. Vegetative propagation by stem cuttings with and without 
rooting hormone (Figure 7) shows that the Jamaica seed origin had a good response to vegetative propagation with both rooting hormone and non-rooting hormone with $55.46 \%$ and $88.89 \%$ leaf sprout, respectively. This means when seeds are not available for propagation, the Jamaica seed origin is best to grow in North Florida.

\section{Conclusion}

Moringa oleifera is a drought-resistant tree that withstood the climate of North Florida. Although ten out of the eleven seed origins were able to survive in this harsh environment without irrigation, Nigeria's Local moringa seed origin grew faster in heights compared to Nigeria that grew slowly. Nigeria Local had the highest heights of $191.98 \mathrm{~cm}$ for November 2018 and $123.19 \mathrm{~cm}$ for November 2019, while Texas PKM1 and Nigeria seed origin had lower heights of $91.02 \mathrm{~cm}$ in 2018 and $53.16 \mathrm{~cm}$ in November 2019, respectively. Their characteristics to survive in water-scarce environments qualified them to grow in the sub-tropical climates as the case with North Florida. More research studies need to be done in this respect to establish the heights of Moringa oleifera seed origins used for this study when fully grown alongside other seed origins. Furthermore, pod and seed yields were not determined in these studies.

\section{References}

1. Alhakmani F, Kumar S, Khan SA. Estimation of total phenolic content in-vitro antioxidant and anti-inflammatory activity of flowers of Moringa oleifera. Asian Pac J Trop Biomed. 2013; 3: 623-627.

PubMed: https://pubmed.ncbi.nlm.nih.gov/23905019/

2. Faley JW. Medicinal potential and benefits of Moringa oleifera 13.1 Moringa oleifera medicinal potential and benefits. The Miracle Tree: Moringa oleifera. 2019.

3. Omonhinmin C, Olomukoro E, Ayoola A, Egwim E. Utilization of Moringa oleifera oil for biodiesel production: A systematic review. AIMS Energy. 2020; 8: 102.

4. Li X, Siddique KH. Future smart food. Rediscovering hidden treasures of neglected and underutilized species for Zero Hunger in Asia. FAO Bangkok. 2018.

5. Zaku SG, Emmanuel S, Tukur AA, Kabir A. Moringa oleifera: An underutilized tree in Nigeria with amazing versatility: A review. Afr J Food Sci. 2015; 9: 456-461.

6. Saini R. Dietary iron supplements and Moringaoleifera leaves influence the liver hepcidinmessenger RNA expression and biochemical indices of iron status in rats. Nutr Res. 2014; 34: 630-638.

PubMed: https://pubmed.ncbi.nlm.nih.gov/25150122/

7. Arora DS, Onsare JG, Kaur H. Bioprospecting of Moringa (Moringaceae): microbiological perspective. J Pharmacognosy Phytochemistry. 2013; 1: 193- 215.

8. Kirschbaum MUF. Direct and indirect climate change effects on photosynthesis and transpiration. Plant Biology. 2004; 6: 242-253.

9. Pokhrel CP, Timilsina A, Yadav RKP, Khanal R. Moringa Oleifere: A potential cash crop in Nepal. In International symposium on healthy society \& healthy world. 2016; 33-41.

10. Asante WJ, Nasare IL, Tom-Dery D, Ochire-Boadu K, Kentil KB. Nutrient composition of Moringa oleifera leaves from two agro ecological zones in Ghana. Afr J Plant Sci. 2014; 8: 65-71.

11. Korsor M, Ntahonshikira C, Bello HM, Kwaambwa HM. Comparative proximate and mineral composition of Moringa oleifera and Moringa ovalifolia grown in central Namibia. Sustainable Agri Res. 2017; 6: 31.

12. Lawrimore J. Global Summary of the Year, Version 1.0. NOAA National Centers for Environmental Information. 2016. https://www. currentresults.com/YearlyWeather/USA/FL/Tallahassee/recentannual-tallahassee-temperature-precipitation.php

13. Billings WD. Constraints to plant growth, reproduction, and establishment in arctic environments. Arctic Alpine Res. 1987; 19: 357-365.

14. Korsor M, Ntahonshikira C, Kwaambwa HM, Bello HM. Comparative performance of Moringa oleifera and Moringa ovalifolia seeds and seedlings establishment in central Namibia. Net J Agri Sci. 2016; 4: 35-44.

15. Padayachee $B$, Baijnath $H$. An overview of the medicinal importance of Moringaceae. J Med Plants Res. 2012; 6: 5831-5839.

16. Hassan FAG, Ibrahim MA. Moringa oleifera: nature is most nutritious and multi-purpose tree. Int J Sci Res Publications. 2013; 3: 1-5.

17. Sánchez NR, Ledin S, Ledin I. Biomass production and chemical composition of Moringa oleifera under different management regimes in Nicaragua. Agrofores Sys. 2006; 66: 231-242. 